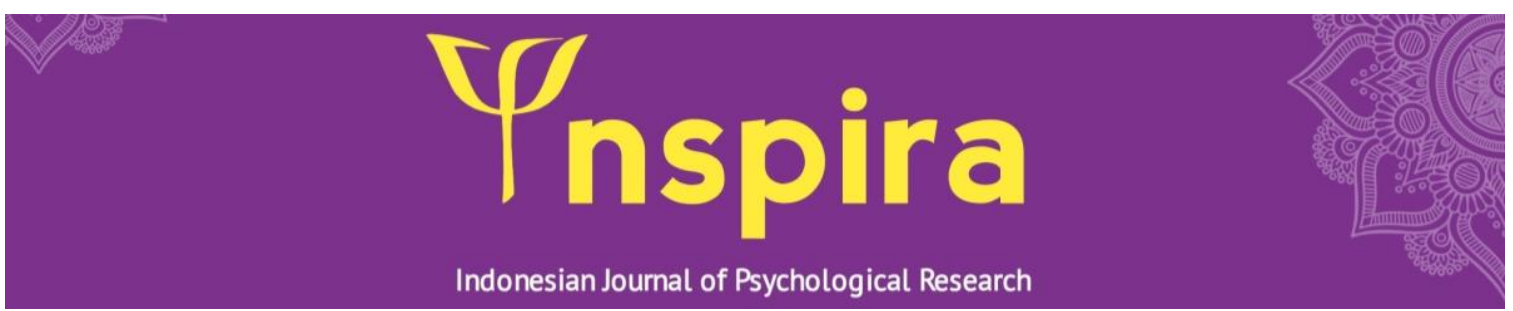

\title{
Actuality and happiness of the soul: An Islamic epistemological perspective
}

Nani Widiawati ${ }^{\circledR}$

Department Islamic Communication and Broadcasting, Institut Agama Islam Cipasung, West Java, Indonesia

\section{${ }^{凶}$ Corresponding author:}

Nani Widiawati (email: widiawatinani96@gmail.com)

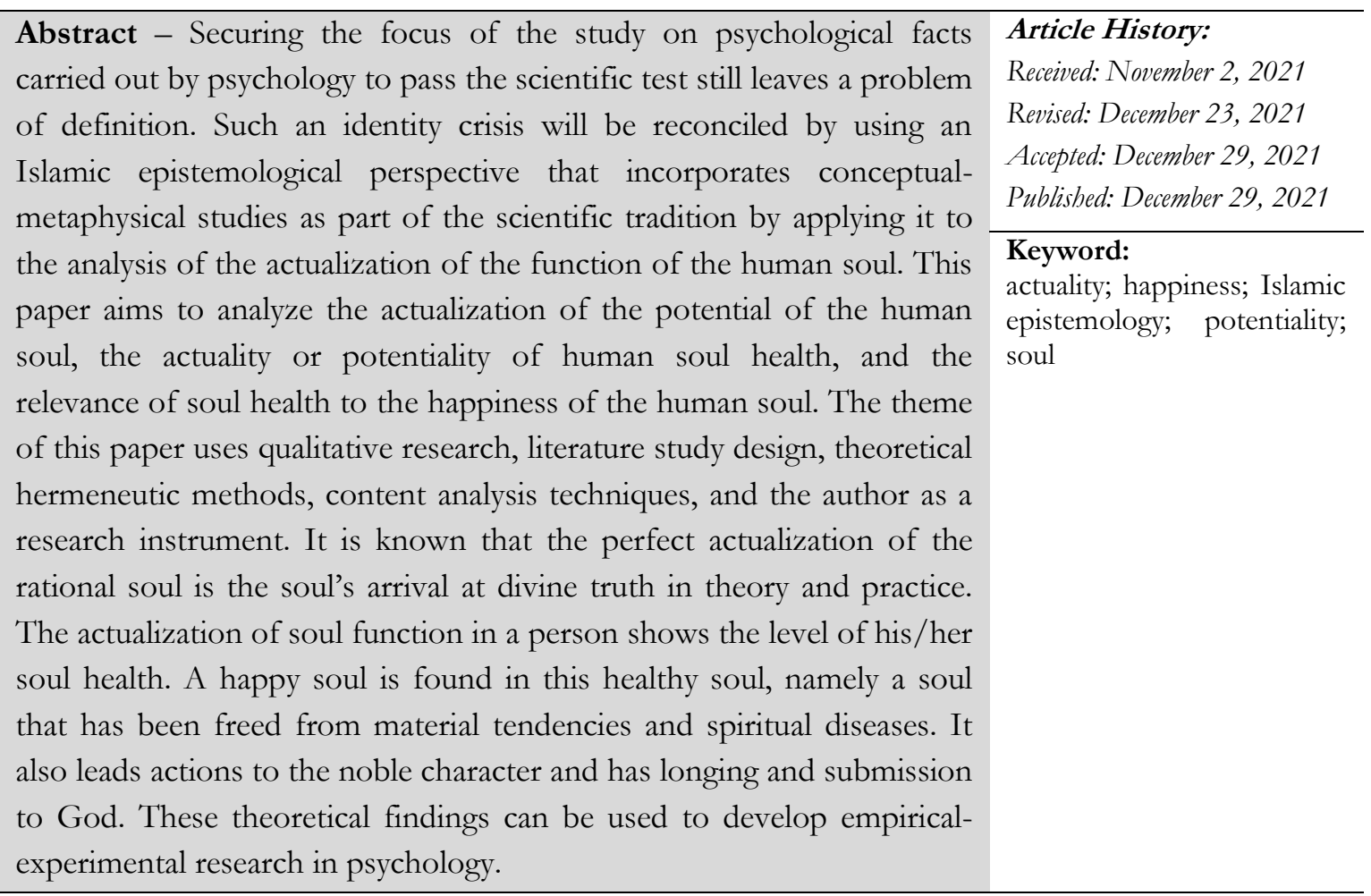

\section{How to cite (APA $7^{\text {th }}$ Edition)}

Widiawati, N. (2021). Actuality and happiness of the soul: An Islamic epistemological perspective. INSPIRA: Indonesian Journal of Psychological Research, 2(2), 81-93. https://doi.org/10.32505/inspira.v2i2.3430 


\section{INTRODUCTION}

Happiness is the goal of all humans (Presentation \& Janello, 2021). Everything that humans do always leads to efforts to achieve happiness. The concept of happiness has been constructed by psychologists with their scientific approach, philosophers with their rationalconceptual approach, and metaphysicists with their spiritual approach. The epistemology of positivism is separated from the rational-conceptual and spiritual discussion because it is outside the discussion of the scientific area recognized by the philosophical system. However, this is not the case with Islamic epistemology. Rational and spiritual objects have an ontological status that can be accounted for so that a study of them produces the science of the soul itself, the science of the soul. Psychology as the science of the soul, not about mental facts, was born from the branch of metaphysics. While psychology, which deals with mental facts, was born from a branch of science (Baumeister et al., 2007; Dominski et al., 2018; Lundh, 2018; Molenaar, 2004; Oaksford \& Chater, 2020; Pérez-Álvarez, 2018; Zilio, 2016).

The description of psychological categorization in metaphysical and scientific studies spontaneously shows the fundamental difference between the epistemology of positivism and the epistemology of Islam. In the Islamic epistemological system, the area of scientific study is not limited to the empirical area but all areas recognized by Islam, including the metaphysical area. With the variations in the study area, metaphysics is accommodated into knowledge that is categorized as science (Widiawati, 2021a, 2021b). In the epistemological system of positivism which emphasizes empirical criteria in the area of study, purely conceptual-metaphysical are marginalized. To fulfill its epistemic foundation, psychology must be supported by a philosophical foundation that includes three things, namely empirical, positive, and falsifiable (Al Yusainy, 2015). With these criteria, psychology as the science of soul processes or the soul itself becomes a reasonably serious conversation (Hastjarjo, 2015).

This paper focuses on psychology as part of the branch of metaphysics from the perspective of Islamic epistemology. With this area and perspective, the happiness in question comes from the soul itself, not facts about the soul's happiness or happiness as a positive emotion subjectively determined by each person (Abde \& Salih, 2015), but an objectively constructed theory of happiness. In addition, the meaning of the soul is dominated by discussions of the rational soul as a specific human soul. This paper begins with the assumption that mental happiness reflects a healthy soul, and a healthy soul is marked by the actualization of the function of the soul itself. Thus, this study aims to analyze the actualization of the potential of the human soul, the actuality or potentiality of human soul health, and the relevance of soul health to human soul happiness.

The discussion concerning the theme of the human soul actuality in the context of health and happiness for the human soul does not seem to have been comprehensively studied by other researchers. Several studies discuss mental health from a theological perspective (Abde \& Salih, 2015; Ariadi, 2019; Fitrianah, 2018; Samain \& Budihardjo, 2020) and in other studies associated with Islamic counseling (Aristiana et al., 2017; Najamuddin, 2018), Islamic therapy (Nurhayati, 2016), worship (Lubis et al., 2019), or Islamic education (Mulyani, 2020). Theological perspective is also used to discuss the concept of happiness and compare it with Greek philosophy (Hamim, 2016; Shaeful RS, 2011) or Islamic philosophy (Azmi \& Zulkifli, 2018). Some studies use a philosophical perspective to reveal the thoughts of scientists 
(Arrasyid, 2020; Damanik, 2020; Fuadi, 2018; Rahmadon, 2020) and Muslim philosophers (Arif, 2019; Fauzi, 2019) about happiness or comparisons of thoughts between scientists (Ayob, 2020). However, exploring the concept of soul happiness based on the actuality of human psychological functions and discussed in the perspective of Islamic epistemology seems to have not been carried out by other researchers.

On that basis, research on the actuality of the soul function in soul happiness becomes important to fill research in this field. In addition, related to polemics about psychology as a science that examines the facts of the soul or the soul itself can be brought together by presenting the format of psychology in the realm of metaphysics as expressed in this paper

\section{RESEARCH METHOD}

The theme of the actuality of the soul function and the happiness of the human soul is discussed through qualitative research with a literature study design. This research can be identified as philosophical research that uses a theoretical hermeneutic method to discover substantive theory in its field. The data in this study refers to written data sources related to the research topic. In this case, data regarding the soul's actuality is focused on the thoughts of alGhazali, al-Farabi, and Ibn Sina. Al-Ghazali's thoughts on this matter are contained in the book Al-Munqidh min al-Dhalal, the primary data, while Ibn Sina and al-Farabi are taken from the translation of Muhammad Uthman Najati's writing entitled Al-Dirasat al-Nafsaniyab inda al'Ulama al-Muslimin, which is secondary data. Data were collected through content analysis techniques.

The researcher is positioned as a research tool or human instrument in this study. As a tool, the researcher plays a role in preparing research designs, adapting designs to the substantive character of research data, identifying credible data sources, and developing data collection techniques. By positioning herself as an instrument, the author can explore various data found by setting the focus of the research, determining the research design, selecting representative and credible data, assessing the quality of the data, being the perpetrator of data collection, and interpreting the data.

\section{RESULT}

Kaplick \& Skinner (2017) mention psychology in Islam as an interdisciplinary study that explores human nature based on Islamic sources which aim to bring humans to their best state, physically, spiritually, cognitively, and emotionally. In Islamic epistemology, these traits refer to the potential of the human soul. This soul potential is the motor that drives the human body as a tool for the soul. If the function of the soul can be perfectly actualized on the device, then the soul is in a healthy condition. Furthermore, the healthy condition of the soul engenders happiness for the human soul.

\section{Actualization of the potential of the human soul}

Humans have three soul potentials: the plant, the animal, and the rational soul. Through the potential of the soul that they have, humans are at the highest hierarchy in the structure of living things because they have the potential of souls from creatures in the hierarchy below them, namely animals and plants. Humans have the potential to actualize all the potentials of 
all living things. The plant soul has a function in terms of giving birth (al-quwwah al-muwallidab), growing (al-quwwah al-murabbiyah atau al-quwwah al-munammiyab), and the potential on absorbing food (al-quwwah al-ghadriyah) (Najati, 2002).

The generative potential carries out a generative function: the power that takes from a potentially similar part. The growth power works in terms of the maintenance or growth of the body by carrying out the function of growth or body parts for its perfection and development, namely increasing the whole body, which is transformed by food. Through the power of nutrition, then like plants, the power of human nutrition has a function in converting food into body shape.

Understanding (al-idrak) is the process of accepting the subject who understands (almudrik) the description of the object to be reached (al-mudrak). If the image is taken, the potential for understanding will bind knowledge so that it manifests in memory even though the object image has disappeared from the senses (Najati, 2002). The potential for understanding is divided into two potentials: the potential for understanding externally (alquwwah al mudrikah min al-kharij) and internally or internal senses. The former involves understanding external objects through the five external senses such as hearing, seeing, tasting, smelling, and touching. The former has something to do with the collective senses (al-hiss almusytarak), conception (al-quwwah al-mushawwitab), fantasy (al-quwwab al-mutakhayyilab), estimation (waham), and memory or memorization (al-dzakirah or al-hafizhah) (Najati, 2002).

External sensory potentials carry out the functions of sensory perception. Through sensing, there is a process of receiving sensory power to sensory images, and through perception, there is a process of receiving perceptual images. Practically, some senses function as tools of life, which are used to maintain their survival, and some of the other senses are perfect for their being (Najati, 2002).

The potential of the internal senses performs functions according to the capacity of each tool. The collective senses are the center for gathering all the sensory images from the five external senses. In the collective senses, the essential characteristics of all sensory stimuli are collected to be distinguished from one another. Conceptual potential serves as a place to store images that persist even though the sensory stimulus has been lost. The fantasy potential is to recall, collect, separate sensory images, or arrange them into new forms. Potential fantasy can imagine something that has passed or is expected to happen. This potential plays a role in the process of remembering and thinking. Potential estimation understands the non-sensory partial meanings that exist in external sensory objects so that an object's positive or negative meaning can be known. Memory or memorization, the last internal sense potential, is for keeping nonsensory meanings in the sensory stimulus captured by the estimation potential.

The second potential possessed by the animal soul is the driving potential (al-quwwab almubarrikah). This potential encourages common movements to accomplish the work the animal desires. The realization of action is driven by the movement of the potential of desire. The potential for desire itself is divided into the potential for lust and the potential for emotion. The potential for lust is the potential that pushes you towards something that is considered necessary, enjoyable, and valuable, while the potential of emotion encourages you to stay away from something that is considered dangerous or damaging. 
The third human soul is the rational soul. This rational soul is a uniquely human soul. This soul is for rationalizing rational things, distinguishing between beautiful and bad things, and producing science and technology. This rational soul is classified into practical and theoretical intellects. Theoretical intellect is also known as scientific intellect. This intellect plays a role in perceiving universal portraits free from matter. This intellect has been created for humans to achieve happiness. The analogy of the rational soul with theoretical intellect is the analogy of a mirror with the image reflected from it. With such an analogy, rational things in Divine emanation will be clearly illustrated through theoretical intellect as an image reflected from a mirror.

Al-Farabi divides rational intellect into three levels, namely material intellect (bayulani), actual or habitual intellect (al-'aql al-munfa'i), and acquired intellect (al-'aql al-mustafad). Ibn Sina added talent/possession intellect (al-'aql bi al-malakab) to the second hierarchy after material reason so that it becomes four levels. Potential intellect is the absolute readiness of humans to grasp rational things before they are actual, as the readiness of a child learns how to write. As a potential, the potential of this soul is still a possibility or potential to reason because this intellect does not yet contain rational objects. Habitual intellect can perceive the basic principles of thinking without going through a laborious reasoning process. The actual intellect can think about rational objects. This intellect can be examined at any time due to the intellect that thinks without effort. The human intellect has reached perfection at this stage because it already contains rational objects. When all the objects of intellect are achieved, or most of them are active ma'qul, the actual mind shifts to the highest level of intellect, namely acquired intellect. Acquired intellect is free from matter, and its existence is close to the Active Intellect. As the intellect with the highest hierarchy, the acquired intellect is the part of the soul that is not damaged even if the body is destroyed (Najati, 2002).

Practical intellect, which is the second potential of rational intellect, functions to conclude the tasks of humanity, morality, and professionalism. With this function, practical intellect serves as a controller for action so that the actualization of theoretical knowledge constructed by the theoretical intellect can be adequately realized. (Gutas, 2012; Najati, 2002).

\section{Human soul health: Actuality or potentiality}

The actualization of the potential of the human soul depends on the dominance of each soul. A person's character depends on the dominance of the three potential souls possessed by humans. A person's life can reflect on the characters of plants more dominantly than those of animals or humans. People can reflect more on animal characters than on plant or human characters. However, the perfection of a person's soul as a human only occurs when reflecting on human character. With this character, a person will always try to serve his or her rational soul, and through this trait, it is known that his or her rational soul is no longer potential but actual. Because the rational soul is a unique human soul, a study of the health and happiness of the human soul will focus on the study of the rational soul.

Potential is the ability to act (Bagus, 1996). As the ability, potential does not refer to a particular actual being. When it exists in its potential, the human soul does not realize any existence. Potential becomes actual when it exists. In the perspective of al-Ghazali (1996), the tools of knowledge in humans are actualized in stages: the senses, the intellect, then the heart. When only the senses are actualized, the rational area and the metaphysical area become a dark 
area. The rational area for the sensory soul is closed because the potential of the intellect is not yet actual. The closed domain of reason is a matter of potentiality.

In principle, every substance always actualizes its unique potential. The intellectual potential is the actuality of thinking work. In terms of potential, the soul has the possibility to reflect on its function. However, as is a necessity for a potential, its actuality at one time is not specific. Even though the potential of acquired intellect is characterized by its ability to mediate with Tenth Intellect, its actualization cannot be ascertained. Likewise with the actual character. Theoretically, the habitual intellect is already capable of thinking about rational concepts, but as it is the basis of the inevitability of its potential being, its actualization can be positive and even negative. Potential being is distinguished from actual being because its being cannot be ascertained. Potential has no actuality principle.

At its earliest stage, the theoretical rationale soul of man, namely potential reason, is full potential. It does not yet contain rational concepts, so the thinking ability of the soul is not yet actual. When this soul can think about simple rational principles, its habitual intellect is actual. The habitual intellect moves from habitual potentiality to habitual actuality. This mind already contains simple rational concepts to think about simple rational principles as well. In this way, if one is put in a position to think about complex rational concepts, their habitual reason cannot reach them. This is not a question of being intelligent or unintelligent but is necessary for the question of actuality or potentiality.

The actuality of the function of the soul, if it follows the active and passive categorization (Bagus, 1996), is active. The function of the soul is not in the realm of pure possibility, which agents only fully actualize outside of itself. With its active nature, the intellect has an innate ability or tendency to become or run something specific according to its reality (Bagus, 1996). On this basis, the human intellect has the potential to think because thinking is a potential that is only possessed by intellect, not by other soul potentials. For some reason, it can happen not to think, but only because of the potential to think; it is called reason.

However, before actualizing, the function of reason is full potential. The actualization of potential being into actual requires a cause, which in Aristotle's thought refers to four causes: material cause, efficient cause, formal cause, and final cause. The ultimate cause of all that exists is God. However, God is not the direct cause. In the series of emanations, the actualization of the human intellect occurs after the thought process in the Tenth Intellect. As a consequence of his thinking about God, the intellect identified as the Angel Gabriel then actualizes the human intellect's function. Thus, the Tenth Intellect becomes the actual agent that acts as an adequate cause in actualizing the potential of human intellect.

The actualization of the function of the human soul shows the level of soul health in question. The embodiment of this function can be seen from the reflection of the soul's actions both in mental situations, words, attitudes, or actions that appear on the tools of the soul, namely the limbs. Theoretically, evidence for the health of intellect can be proven from its ability to construct theoretical knowledge whose truth can be justified both formally and materially. Formally the truth must be explained methodologically, and materially must be able to touch the essence of truth. Knowledge constructed by intellect must be actual knowledge. Because the ultimate truth belongs only to God, the truth that is reached by theoretical intellect should be part of divine knowledge. This ultimate truth is obtained from the mediation of the 
human mind with the Tenth Intellect, which overflows with divine knowledge. On the other hand, if the achievement of the intellect is not in line with its optimal actualization, that is, it reaches divine knowledge, then the soul health will be disturbed.

Practically, the form of soul health is when it plays its function as a controlling power for a person in living his or her life. A controlled life by maintaining consistency with the achievement of theoretical knowledge reflects the health of his practical intellect. Practical intellect plays a role in guiding behavior in harmony with divine values. Quoting Avicenna's opinion (Nasution, 2002), practical intellect functions to control the human body, so the passions contained in the body do not prevent the theoretical mind from bringing humans to a high level to achieve perfection. In this way, rational soul health is shown by the actual function of the soul in constructing true knowledge and aligning its life according to that proper knowledge. In other words, human soul health requires two things, namely, thinking right and acting right.

In some humans, their rational soul is not yet actual. Their theoretical rational soul has health problems, so they cannot think properly. Their lives are far from the truth because they do not have true knowledge. At the same time, others are able to think right but are not able to live on the path of truth. The inability of the soul, in this case, is related to the actuality or potentiality of the soul. A soul that cannot actualize its function indicates a soul whose health is being disturbed. The rational things in Divine emanation are not clearly illustrated in his theoretical intellect. The reflection of the image of God's light is damaged, so the intellect is bounced on the furthest circuit of the emanation system.

\section{Health soul and the happiness of human}

Daradjat (1969) defines mental health as the realization of genuine harmony between mental functions and the creation of adjustment between the individual and himself or herself and his or her environment based on faith and piety. Mental health is an individual's ability to manage mental functions and create adjustments with oneself, others, and the surrounding environment dynamically based on the Qur'an and Sunnah as a guide to life towards happiness in the world and the hereafter (Ariadi, 2019).

In Islam, soul health is related to the concept of happiness. Happiness is marked by the actualization of a person's soul function, which is externally reflected in his or her attitude and behavior. Reflection of a healthy soul is shown by a person's ability to make himself or herself and others happy. This evidence makes psychology define attitudes and behavior as its area of study; even if defined lexically, psychology is defined as the science of the soul. Every soul has its own needs. When its needs are met, the soul finds its happiness. The need of the rational soul is its inclination towards knowledge. The rational soul always longs for truth and is always called to find it. The rational soul loves science. The actualization of the rational soul is stratified according to the rational readiness of each level.

The perfection of the theoretical intellect is when it reaches the top of the hierarchy; that is, the acquired intellect is actual. To reach this stage, humans must live a life of asceticism to master all forms independent of matter. This effort will give birth to readiness in the soul to accept pure forms or acquired intellect bestowed by Active Intellect (Dahlan, 2003). At this stage, the intellect has freed itself from all material ideas. Moreover, the soul's happiness is obtained when the soul has detached itself from all material things. 
However, the pinnacle of theoretical intellect still requires the control of the practical intellect. This is because the plant and animal souls can prevent the rational soul from reaching perfection. That is why the practical intellect struggles to control the potential of the souls of plants and animals, so the rational soul is perfectly actualized (Dahlan, 2003). The perfect actualization of the rational soul is when its theoretical achievements are manifested in attitudes and behavior. The perfection of the actualization of the intellect is a reflection of happiness for the soul.

When the perfection of the actualization of the intellect is reached by trying to free oneself from the dependence of the soul on the material world by practicing asceticism, it appears that happiness is realized in noble character. If it is understood with reverse logic, happiness can be achieved by doing various good deeds. It seems that the rationalization of the practice of asceticism institutionalized in the concept of maqamat in the Sufi tradition is still understood in reverse, that morality is closely related to happiness. To achieve happiness, one must reflect on the noble character in his or her life. People who have good morals are people who are healthy in spirit so they can achieve various spiritual happiness.

People whose souls are sick will be far from happiness. This can be analogous to a person whose senses are impaired due to a physical illness, such as influenza. Food that should taste good becomes bitter or tasteless, likewise with someone whose soul is sick. Diseases that hit the soul are diseases that can prevent a person from doing good. That is why his or her soul suffers. Among the mental illnesses is the disease of lust, jealousy, pride, and others. These diseases can prevent a person from feeling spiritual happiness. Thus, happiness is identical to the realization of good deeds.

For the soul, bad behavior is suffering. This suffering can be detected when someone does evil deeds. Corruptors do mark up financial data secretly so that people do not know. That means corruptors know that corrupt acts are evil deeds. Corruptors get wealth as a result of their corruption. However, what will happen if they are asked whether they are happy with the evil deeds? If it is known that the corruptors hide the results of their corruption as a reflection of feelings of insecurity or always feel worried if their actions are revealed, then it is inevitable that evil deeds cannot produce happiness. Feelings of fear, anxiety, worry, and so on are evidence that a person will not feel happiness by doing bad deeds because his or her conscience knows the bad things he or she does.

The suffering is related to the interference of other potential souls, namely the plant and the animal soul. Desires, emotions, senses, fantasies, and so on can distort the reflection of knowledge into the theoretical intellect. When the other elements of the soul are preoccupied with other material things, therein lies the soul's suffering because the things it needs are not fulfilled. If it is free from the domination of other souls, the rational soul will see the highest realm of imaginal (al-malakut al-a'la) and achieve perfect happiness. (Najati, 2002).

\section{DISCUSSION}

The concept of soul health is closely related to the concept of mental health or mental hygiene. The word mental, which comes from the Latin word mens or mentis (Burhanuddin, 1999), has the same meaning as "psyche," which means psychic, soul, or psyche. Among the understandings put forward by Daradjat (1969) regarding mental or mental health is the 
avoidance of a person from the symptoms of mental disorders (neuroses) and symptoms of mental illness (psychoses). Another definition is the realization of true harmony between the functions of the soul and having the ability to deal with common problems and feel optimistic about one's own happiness and abilities.

From an Islamic perspective, the soul health concept is defined as an individual's ability to manage the realization of harmony between soul functions and the creation of adjustments with oneself, others, and the surrounding environment dynamically, based on the Qur'an and Sunnah as a guide to life towards happiness in the world and the hereafter. (Ariadi, 2019).

As part of a philosophical system that was born from the womb of Islam, Islamic epistemology makes Islam with its primary source, namely the Qur'an and Sunnah, as an umbrella in thinking. Thus, epistemological reflection on soul health and happiness comes from Islamic teachings. On the other hand, psychology has had its generic meaning of soul health. Thus, the epistemological perspective on the actualization of the soul in the context of its health and happiness is shaded by Islamic teachings on the one hand and borrows psychological terminology as a measuring tool to analyze the problem.

Judging from its hierarchy that transcends the potential of the plant soul and animal soul, the function that the rational soul actualizes shows that the true happiness for humans lies in spiritual happiness, not material or sensual happiness. The happiness of the rational soul is of a higher quality than the happiness of the animal soul or the plant soul. The animal and pant souls are related to physical objects. The happiness that arises from these two souls is temporal. Happiness that is essential for human beings is related to rational objects.

Intellect is a spiritual entity, so its proximity to material things will further reduce the quality of happiness for the human soul. As a spiritual entity, the intellect must be free from its connection with material reality. The independence of the intellect from material objects is a virtue for the intellect and is related to the perfection of the spirit. Therefore, the purpose of the journey of intellect is disinterest and detachment from the material world, so it will further perfect the soul by reflecting actions that are in harmony with rational goodness. Such a soul exists so closely with divinity that it can attain eternal happiness (Natsir, 2014).

The issue of soul happiness is related to soul health, while soul health itself is synonymous with purity. Purity in the soul means that the soul has arrived at the closest circle in the series of emanations, so it is close to the First One, the source of true happiness. To achieve the soul's happiness, humans must be pure to penetrate the veils of the unseen. A pure soul can transcend sensory reality into the realm of actual testimony and eternal beauty (Madkour, 1993). Happiness is what is the goal for the soul. Quoting al-Farabi's opinion (Madkour, 1993), the soul's happiness occurs when the human soul becomes perfect in a form whose existence no longer requires material things. Happiness for the soul is its inclination to the highest realms, not the other way around. In the highest realms, the human soul finds immortality without mortality, majesty without humiliation, pleasure without suffering, and security without fear (Arif, 2019).

The happiness born of material objects is sensual happiness. A more appropriate technical term to describe sensory happiness is pleasure, namely happiness that is temporal and only has a horizontal dimension (Hamim Khairul, 2016). Happiness as such is not a need for a rational soul but a need for an animal and plant soul. If one's is preoccupied with the fulfillment of physical happiness, his or her rational power is not actualized because the animal soul or plant 
soul dominates him or her. In this way, their life is controlled by the dominance of the two souls so that the behavior is similar to plant or animal. Like plants, their life orientation is only to fulfill their basic needs, such as meeting their food needs to continue life or have a family. Like animals, his or her life has mobility, but his or her orientation is again only to meet material needs. Without a rational soul, these two potentials can corrupt a person, and their actions can be worse than animals (Al-A'raf: 179) because it is not based on knowledge, so life is far from the truth. The rational soul is a soul inclined to knowledge, truth, and God. This soul has a longing and submission to God. It is in harmony with its nature as a servant of God and reflects its servitude into noble character. Reflection of noble character is evidence for the happiness of the rational soul.

A philosophical discussion about the actuality and happiness of the human soul shows a theoretical relevance between the actualization of the function of the human soul and its happiness. However, as with philosophical discussions in general, the constructed theory only comes to a grand theory that is still abstract. Epistemologically, this is good news for the discipline of Islamic psychology in directing the development of its theoretical constructs. The theoretical paradigm found in this research can only be connected to the empirical world. In this world, humans actualize the function of their rational soul when experts contextualize this grand theory in the field by giving birth to middle-range theory, so this grand theory becomes a systematic effort to be used as a research paradigm for empirical studies in psychology. For this effort, further research that initiates the birth of middle-range theory is open to further researchers.

\section{CONCLUSION}

The actualization of the rational soul marks human perfection as a uniquely human soul. The actuality of the rational soul is when theoretically, someone arrives at the nature of truth and practically reflects it in his or her actions. The perfect actualization of the rational soul in a person is shown in the ability to think and act rightly.

The actuality of the function of the soul in humans is not the same. Some souls are still trapped in potentiality. The actualization of the function of the human soul shows the level of mental health in question. The closer the rational soul to divine knowledge and action, the healthier it is. On the other hand, the farther the rational soul is from divine knowledge and action, and the more disturbed its soul health will be. Human mental health requires two things: a person can think right and act right.

A healthy soul is linear with a happy soul. As a spiritual entity, the soul's happiness is marked by releasing other souls with material tendencies. In order to give up material qualities, the soul must be free from spiritual ailments by purifying the soul and adorning it with noble character. Chastity is the goal for a happy soul.

\section{REFERENCES}

Abde, A. N. Y., \& Salih, K. (2015). The literature of happiness "With reference of the philosophy of happiness in Islam." Journal of Islamic Studies and Culture, 3(2). https://doi.org/10.15640/jisc.v3n2a18 
Al-Ghazali. (1996). Al-Munqidh min al-dhalal. Darul-Fikr.

Al Yusainy, C. (2015). Quo vadis psikologi sebagai sebuah kajian ilmiah? Buletin Psikologi, 23(1), 51. https://doi.org/10.22146/bpsi.10577

Ariadi, P. (2019). Kesehatan mental dalam perspektif Islam. Syifa' MEDIKA: Jurnal Kedokteran Dan Kesehatan, 3(2), 118. https://doi.org/10.32502/sm.v3i2.1433

Arif, M. (2019). Pendidikan kejiwaan dan kesehatan mental (Perspektif Fakhruddin ar-Razi). Farabi, 16(2), 161-180. https://doi.org/10.30603/jf.v16i2.1081

Aristiana, N. F., Bukhori, B., \& Hasanah, H. (2017). Pelayanan bimbingan dan konseling Islam (Studi kasus pelayanan klinik VCT Rumah Sakit Islam Sultan Agung Semarang dalam meningkatkan kesehatan mental pasien HIV/AIDS). Jurnal Ilmu Dakwah, 35(2). https://doi.org/10.21580/jid.v35i2.1609

Arrasyid, A. (2020). Konsep kebahagiaan dalam tasawuf modern Hamka. Refleksi: Jurnal Filsafat Dan Pemikiran Islam, 19(2). https:// doi.org/10.14421/ref.2019.1902-05

Ayob, M. A. S. (2020). Perspektif Hamka dan Aristotle mengenai kebahagiaan. Jurnal Hadhari 12, 12(June).

Azmi, M. N., \& Zulkifli, M. (2018). Manusia, akal dan kebahagiaan (Studi analisis komparatif antara al-Qur'an dengan filsafat Islam). Al Qalam: Jumal Ilmiah Keagamaan Dan Kemasyarakatan, 12(2), 127. https://doi.org/10.35931/aq.v0i0.75

Bagus, L. (1996). Kamus Filsafat (1st ed.). Gramedia.

Baumeister, R. F., Vohs, K. D., \& Funder, D. C. (2007). Psychology as the science of selfreports and finger movements: Whatever happened to Actual behavior? Perspectives on Psychological Science, 2(4), 396-403. https://doi.org/10.1111/j.1745-6916.2007.00051.x

Burhanuddin, Y. (1999). Kesehatan mental. CV Pustaka Setia.

Dahlan, A. A. (2003). Pemikiran falsafi dalam Islam. Djambatan.

Damanik, N. (2020). Konstruksi kebahagiaan dalam tasawuf modern Hamka. UIN Sumatera Utara.

Daradjat, Z. (1969). Kesehatan mental. Gunung Agung.

Dominski, F. H., Vilarino, G. T., Coimbra, D. R., Silva, R. B., Casagrande, P. de O., \& Andrade, A. (2018). Analysis of scientific production related to sports psychology in sports science journals of Portuguese language. Journal of Physical Education (Maringa), 29(1), 1-14. https://doi.org/10.4025/jphyseduc.v29i1.2930

Fauzi, M. (2019). Filsafat Kebahagiaan Menurut al-Ghazali.

Fitrianah, R. D. (2018). Keseimbangan emosi dan kesehatan mental manusia dalam perspektif psikologi agama. Jurnal Ilmiah Syi'ar, 18(1), 91. https://doi.org/10.29300/syr.v18i1.1285

Fuadi, F. (2018). Refleksi pemikiran Hamka tentang metode mendapatkan kebahagiaan. Substantia: Jurnal Ilmu-Ilmu Ushuluddin, 20(1). https://doi.org/10.22373/substantia.v20i1.3403

Gutas, D. (2012). Avicenna: The metaphysics of the rational Soul. Muslim World, 102(3-4). https://doi.org/10.1111/j.1478-1913.2012.01413.x 
Hamim, K. (2016). Kebahagiaan dalam perspektif al-Quran dan filsafat. Tasamuh, 13(2), 127150.

Hastjarjo, T. D. (2015). Mengintegrasikan psikologi: Peluang atau mimpi? Buletin Psikologi, 16(1), 1-22. https://doi.org/10.22146/bpsi.7492

Kaplick, P. M., \& Skinner, R. (2017). The evolving Islam and psychology movement. European Psychologist, 22(3), 198-204. https://doi.org/10.1027/1016-9040/a000297

Lubis, L. T., Sati, L., Adhinda, N. N., Yulianirta, H., \& Hidayat, B. (2019). Peningkatan kesehatan mental anak dan remaja melalui ibadah keislaman. Jurnal Agama dan Ilmu Pengetahuan, 16(2).

Lundh, L. G. (2018). Psychological science within a three-dimensional ontology. Integrative Psychological and Behavioral Science, 52(1), 52-66. https://doi.org/10.1007/s12124-017-94128

Madkour, I. (1993). Filsafat Islam metode dan penerapannya. Grafindo Persada.

Molenaar, P. C. M. (2004). A manifesto on psychology as idiographic science: Bringing the person back into scientific psychology, This Time Forever. Measurement: Interdisciplinary Research \& Perspective, 2(4), 201-218. https://doi.org/10.1207/s15366359mea0204_1

Mulyani, S. (2020). Urgensi kesehatan mental dalam pendidikan Islam. QALAM: Jurnal Pendidikan Islam Jurusan Tarbiyah - STAI Sufyan Tsauri Majenang, 01 No.02.

Najamuddin, N. (2018). Kesabaran dan Kesehatan Mental dalam Bimbingan Konseling Islam. TASAMUH: Jurnal Studi Islam, 10(1). https://doi.org/10.47945/tasamuh.v10i1.72

Najati, M. U. (2002). Jiwa dalam pandangan para filosof muslim (I). Pustaka Hidayah.

Nasution, H. (2002). Filsafat Islam. Gaya Media Pratama.

Natsir, M. (2014). Komparasi pemikiran Ibnu Sina dan Suhrawardi: Telaah terhadap Teori Emanasi dan Teori Jiwa. Wahana Akademika: Jurnal Studi Islam dan Sosial, 1, 181-206.

Nurhayati. (2016). Kesehatan dan perobatan dalam tradisi Islam. Ahkam, 16(2), 223-228.

Oaksford, M., \& Chater, N. (2020). New paradigms in the psychology of reasoning. Annual Review of Psychology, 71, 305-330. https://doi.org/10.1146/annurev-psych-010419-051132

Pérez-Álvarez, M. (2018). Psychology as a science of subject and comportment, beyond the mind and behavior. Integrative Psychological and Behavioral Science, 52(1), 25-51. https://doi.org/10.1007/s12124-017-9408-4

Presentation, V., \& Janello, M. (2021). The happiness principle: Why we need a personal philosophy of bappiness. 1-20.

Rahmadon, R. (2020). Kebahagiaan dalam pandangan Thomas Aquinas dan Hamka. Ushuluna: Jurnal Ilmu Ushuluddin, 1(2). https:/ / doi.org/10.15408/ushuluna.v1i2.15159

Samain, \& Budihardjo. (2020). Konsep kesehatan mental dalam al-Qur'an dan implikasinya terhadap adversity quotient perspektif Tafsir al-Misbah. Jurnal Pendidikan Agama Islam, 1(2), 18-29. https://jurnal.iain-bone.ac.id/index.php/attadib/article/view/961

Shaeful RS, A. (2011). Rahasia kebahagiaan. Jaqfi: Jurnal Aqidab Dan Filsafat Islam, 3, 97-105.

Widiawati, N. (2021a). Filsafat islam (1st ed.). Pustaka Ellios. 
Widiawati, N. (2021b). Pluralisme metodologi diskursus sains filsafat dan tasamuf (M. Miswari (ed.); 2nd ed.). Edu Publisher.

Zilio, D. (2016). On the autonomy of psychology from neuroscience: A case study of skinner's radical behaviorism and behavior analysis. Review of General Psychology, 20(2), 155-170. https://doi.org/10.1037/gpr0000067 